\title{
EBMT-NIH-CIBMTR Task Force position statement on standardized terminology \& guidance for graft-versus-host disease assessment
}

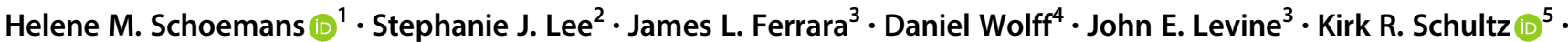 \\ Bronwen E. Shaw ${ }^{6}$ - Mary E. Flowers ${ }^{2} \cdot$ Tapani Ruutu $^{7}$ - Hildegard Greinix ${ }^{8}$ - Ernst Holler ${ }^{4}$. Grzegorz Basak $\mathbb{D}^{9}$. \\ Rafael F. Duarte ${ }^{10}$. Steven Z. Pavletic ${ }^{11}$ on behalf of the EBMT (European Society for Blood and Marrow \\ Transplantation) Transplant Complications Working Party and the "EBMT-NIH (National Institutes of Health) \\ -CIBMTR (Center for International Blood and Marrow Transplant Research) GvHD Task Force"
}

Received: 25 October 2017 / Revised: 5 March 2018 / Accepted: 3 April 2018 / Published online: 5 June 2018

(c) The Author(s) 2018. This article is published with open access

\begin{abstract}
Several international recommendations address the assessment of graft-versus-host disease (GvHD) after hematopoietic cell transplantation (HCT). This position statement by GvHD experts from the European Society for Blood and Marrow Transplantation (EBMT), the National Institutes of Health (NIH) and the Center for International Blood and Marrow Transplant Research (CIBMTR) reviews the existing guidelines for both acute and chronic GvHD, addresses potential confusions that arise in daily practice and proposes consensus definitions for many key terms. We provide a historical perspective on the currently available guidelines and recommend the Mount Sinai Acute GvHD International Consortium (MAGIC) criteria for acute GvHD and the NIH 2014 criteria for chronic GvHD as the most comprehensive and detailed criteria available. This statement also offers practical guidance for the implementation of these recommendations and a set of consensus definitions for commonly used GvHD terms in order to facilitate future clinical and translational research. To assist the dissemination of these recommendations, a web-application based on this position statement is available (https://www.uzleuven.be/egvhd). We believe that adherence to a common set of GvHD assessment criteria is vitally important to improve the quality of data, compare results of retrospective studies and prospective clinical trials, and make therapeutic recommendations based on quality evidence.
\end{abstract}

These authors contributed equally: Rafael F. Duarte, Steven Z. Pavletic.

Helene M. Schoemans

helene.schoemans@uzleuven.be

1 Department of Hematology, University Hospital Leuven and KU Leuven, Leuven, Belgium

2 Clinical Research Division, Fred Hutchinson Cancer Research Center, Seattle, WA, USA

3 Division of Hematology and Medical Oncology, Tisch Cancer Institute, Icahn School of Medicine at Mount Sinai, New York, NY, USA

4 Department of Internal Medicine III, University Hospital Regensburg, Regensburg, Germany

5 Michael Cuccione Childhood Cancer Research Program, BC Children's Hospital, UBC, Vancouver, Canada

\section{Introduction}

Graft-versus-host disease (GvHD) refers to a clinical syndrome caused by the response of transplanted donor allogeneic cells to histocompatibility antigens expressed on

6 Center for International Blood and Bone Marrow Transplant Research (CIBMTR), Medical College of Wisconsin, Milwaukee, WI, USA

7 Clinical Research Institute, Helsinki University Hospital, Helsinki, Finland

8 Division of Hematology, Medical University of Graz, Graz, Austria

9 Department of Hematology, Oncology and Internal Medicine, Medical University of Warsaw, Warszawa, Poland

10 Hospital Universitario Puerta de Hierro Majadahonda, Madrid, Spain

11 Center for Cancer Research National Cancer Institute, National Institutes of Health, Bethesda, MD, USA 
tissues of the transplantation recipient. It is the most serious complication of allogeneic hematopoietic cell transplantation (HCT). Its recognition and control are key elements of a successful outcome. In fact, the World Health Organization stipulates that data collection and data analysis are integral parts of therapy [1].

In practice, however, the application of basic concepts pertaining to the diagnosis and staging of this condition differs widely among HCT clinicians. The use of the templated data collection forms (such as those used by the Center for International Blood and Marrow Transplant Research (CIBMTR), the European Society for Blood and Marrow Transplantation (EBMT), and the National Institutes of Health/National Cancer Institute (NIH/NCI)) improves standardization by collecting data elements as proposed by published consensus documents but demands significant time from healthcare professionals and researchers.

Several studies have shown a lack of adherence to recommendations and inconsistencies in GvHD evaluation [2-9]. Weisdorf et al. showed in one multi-center study that acute GvHD (aGvHD) grading at HCT centers significantly underestimated disease severity compared to a central, expert review board, with inaccurate evaluation of grade III GvHD in $18 \%$ of cases [7]. In a recent chronic GvHD (cGvHD) intervention trial, up to $10 \%$ of patients entered by GvHD Consortium centers were excluded from study analysis post hoc due to failure to meet diagnostic criteria at the time of inclusion [8].

Such discrepancies are concerning because they can significantly affect the interpretation of GvHD data in clinical trials. Misclassifications have been observed even among experienced HCT and GvHD professionals, and inaccuracies are therefore likely to be even more prominent among less experienced centers. In fact, a recent survey of practice patterns completed by transplant professionals during the annual 2017 EBMT conference showed wide variations in the types of reference guidelines used for GvHD assessments, and up to one third of the survey participants reported a lack of confidence in their ability to apply these guidelines [9]. Of interest, the GvHD assessments of two clinical vignettes became much more consistent and compliant with recent international guidelines when the same cases were evaluated using an electronic tool, the eGvHD App [9] (available at https://www. uzleuven.be/egvhd).

The use of electronic tools to streamline and increase the reliability of the GvHD evaluation process has been advocated by several groups [4, 9-12], but such tools require a clear and broad consensus regarding reference guidelines to guarantee their internal validity. GvHD experts from the EBMT, NIH, and CIBMTR have therefore joined forces to: (1) review the existing guidelines for both acute and chronic GvHD and recommend those best supported by clinical evidence; (2) address confusions that arise in real-life scenarios encountered in clinical practice; and (3) develop consensus definitions for key terms frequently used in the evaluation and monitoring of GvHD. All three issues were addressed during a series of conference calls and manuscript draft reviews between May and October 2017. The mission of this effort is to advance GvHD research through a transparent and unbiased standardization of common elements in GvHD terminology, thereby increasing the quality and precision of the data collected in HCT clinical research and practice.

\section{Issue 1: Standardized assessments of GvHD: a historical perspective}

\section{Acute GvHD definition}

Acute GvHD refers to the appearance of an allogeneic inflammatory response in exclusively three organs: the skin (inflammatory maculopapular erythematous skin rash), the liver (hyperbilirubinemia due to cholestatic jaundice), and the gastro-intestinal (GI) tract (upper and/or lower GI tract manifestations: anorexia with weight loss, nausea, vomiting, diarrhea, severe pain, GI bleeding and/or ileus) [13-16]. The diagnosis must occur in the absence of manifestations of cGvHD [17, 18] (Fig. 1a) and should ideally be supported by positive histological findings, but this is not strictly necessary if no alternative etiology is present.

The Glucksberg aGvHD classification was first proposed in the 1970s based on a cohort of 60 patients evaluated for aGvHD after myeloablative conditioning. This classification staged skin, lower gastrointestinal tract and liver, each on a scale of 0 (absent) to 4 (severe) points (Table 1), to create a final overall grade of I (mild) to IV (life-threatening) [13]. The overall aGvHD grade typically corresponds to the highest grade conferred by the individual staging of each organ, as described in Table 2. Approximately 20 years later, the Keystone aGvHD consensus panel reviewed the outcome of the Glucksberg classification in almost 6000 patients and confirmed the predictive value of maximum aGvHD grade for day 100 mortality [14]. Three major recommendations that resulted from that review were: (1) upper GI tract manifestations, in the presence of a positive biopsy, should be classified as overall grade II aGvHD; (2) GI stage 4 should be based on severe symptoms such as severe pain, bleeding and/or ileus and not diarrhea volume; and (3) functional status should be eliminated as an element of overall grade because of its non-specific and multifactorial etiology. In parallel, the CIBMTR proposed the IBMTR aGvHD classification: this alternative algorithm was based on similar raw organ staging (Table 1) and resulted in a final grade of $\mathrm{A}-\mathrm{D}$ (Table 2), which provided 
a

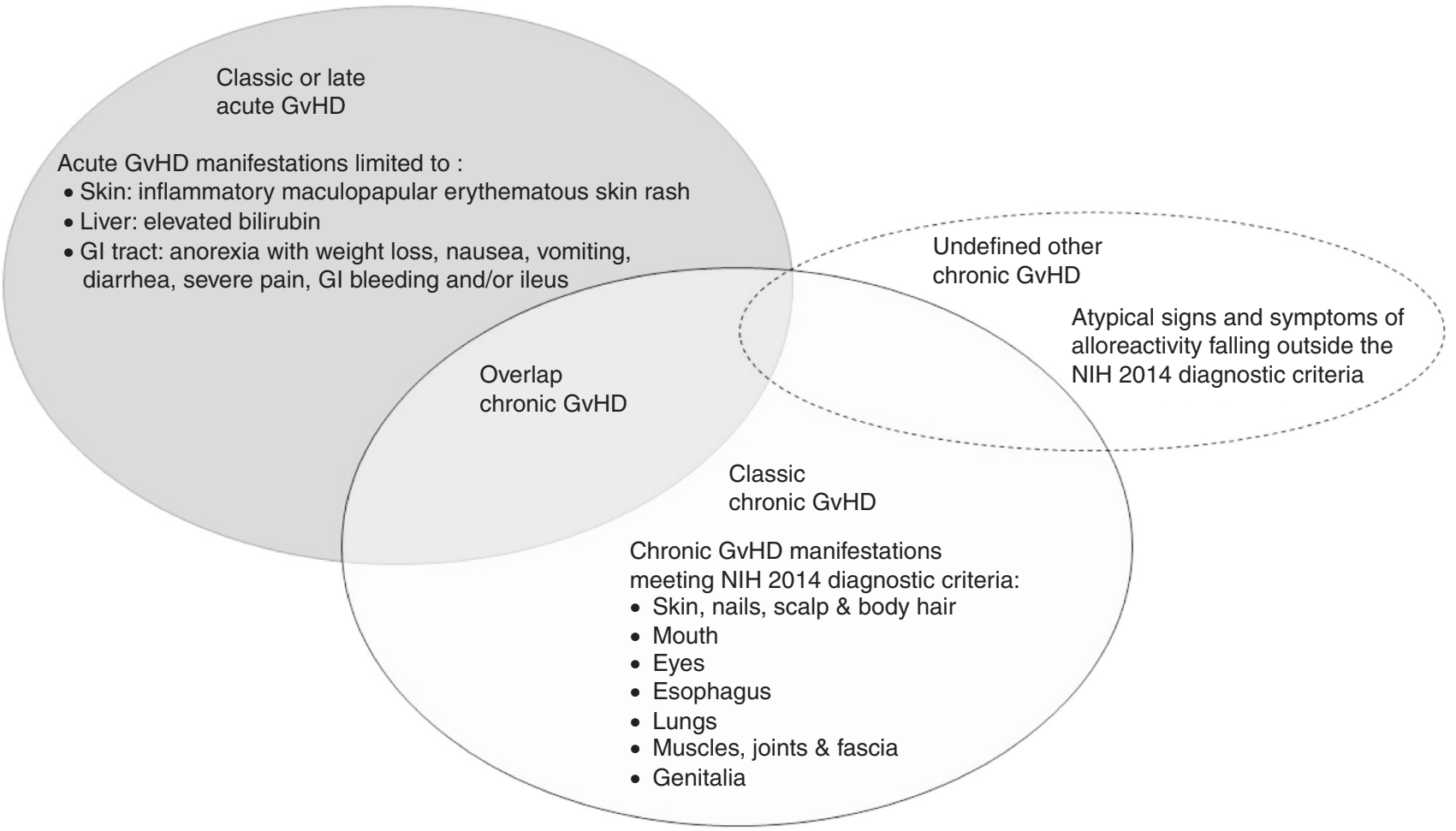

b

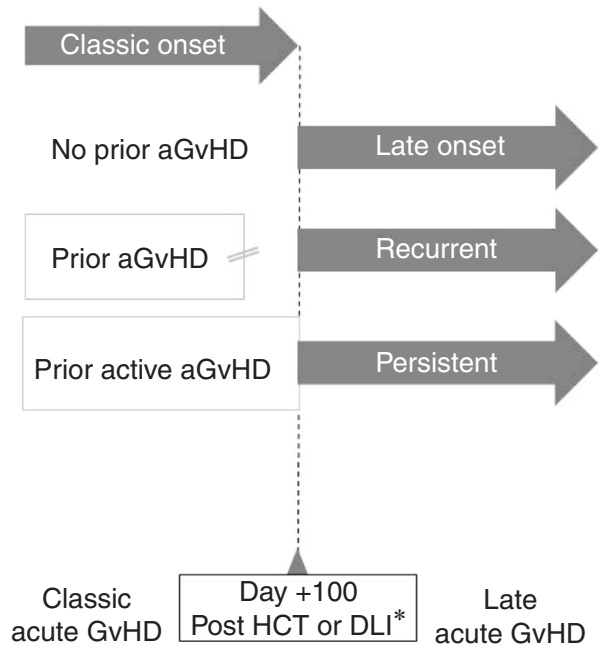

C

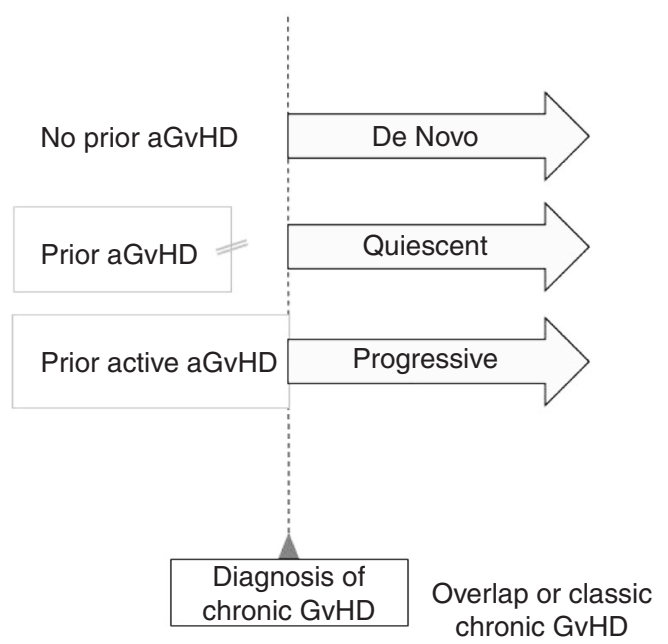

Fig. 1 Schematic representation of the types of GvHD and their onset: a Types of GvHD; $\mathbf{b}$ Types of acute GvHD onset and $\mathbf{c}$ Types of chronic GvHD onset. DLI donor lymphocyte infusion, GvHD graft versus host disease, GI gastro-intestinal tract, HCT hematopoietic cell transplantation, * Controlled, inactive or resolved, * whichever happened last, $\Delta$ GvHD onset.

a slightly more accurate prediction of mortality [15]. Recently, MacMillan and colleagues published a further adaptation of the Keystone consensus criteria: the Minnesota aGvHD grading, which limited overall grade IV aGvHD to skin and gut stage four, instead of skin and liver stage four as described in the Keystone criteria [19] (Table 2). In this study, no particular grading system was superior in predicting survival. The availability of these different options to assess aGvHD can give rise to controversy when healthcare professionals do not clearly define which grading system is used.

Most recently, the Mount Sinai Acute GvHD International Consortium (MAGIC) has revisited these criteria based on a review of their extensive database containing detailed clinical information on aGvHD, and recommended more precise definitions for grade IV aGvHD [16]. 
Table 1 Comparison of the different guidelines available for acute GvHD assessment: individual organ severity staging

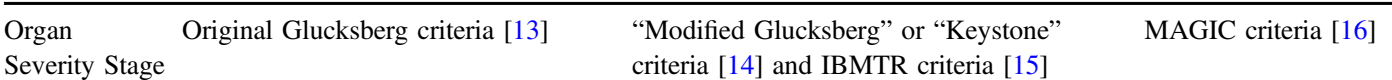

\section{Skin}

0

1

2

3

4

Liver

0

1

2

Upper G

0

Lower GI

1

2

3

4

Karnofsky

index

$\begin{array}{ll}\text { No rash } & \text { No rash } \\ \text { Rash }<25 \% \text { of BSA } & \text { Rash }<25 \% \text { of BSA } \\ \text { Rash } 25 \% \text { to } 50 \% \text { of BSA } & \text { Rash } 25 \% \text { to } 50 \% \text { of BSA } \\ \text { Rash }>50 \% \text { of BSA } & \text { Rash }>50 \% \text { of BSA } \\ \begin{array}{l}\text { Generalized erythroderma } \\ \text { with bullous formation }\end{array} & \begin{array}{l}\text { Generalized erythroderma } \\ \text { with bullous formation }\end{array}\end{array}$

No rash

Rash $<25 \%$ of BSA

Rash $25 \%$ to $50 \%$ of BSA

Rash $>50 \%$ of BSA

Generalized erythroderma ( $>50 \%$ BSA)

plus bullous formation

and desquamation $>\mathbf{5 \%}$ of BSA

Total serum bilirubin $<34 \mu \mathrm{mol} / \mathrm{L}$

$(<2 \mathrm{mg} / \mathrm{dL})$

$$
(<2 \mathrm{mg} / \mathrm{dL})
$$

Total serum bilirubin $34-50 \mu \mathrm{mol} / \mathrm{L}$

( 2 to $3 \mathrm{mg} / \mathrm{dL}$ )

( 2 to $3 \mathrm{mg} / \mathrm{dL}$ )

Total serum bilirubin $51-102 \mu \mathrm{mol} / \mathrm{L}$

( 3.1 to $6 \mathrm{mg} / \mathrm{dL}$ )

( 3.1 to $6 \mathrm{mg} / \mathrm{dL}$ )

( 3.1 to $6 \mathrm{mg} / \mathrm{dL}$ )

Total serum bilirubin 103-255 $\mu \mathrm{mol} / \mathrm{L}$ (6.1 to $15 \mathrm{mg} / \mathrm{dL}$ )

( 6.1 to $15 \mathrm{mg} / \mathrm{dL}$ )

Total serum bilirubin $>255 \mu \mathrm{mol} / \mathrm{L}$ (>15 mg/dL)

Total serum bilirubin 103-255 $\mu \mathrm{mol} / \mathrm{L}$

( 6.1 to $15 \mathrm{mg} / \mathrm{dL}$ )

Total serum bilirubin $>255 \mu \mathrm{mol} / \mathrm{L}$

$(>15 \mathrm{mg} / \mathrm{dL})$

No persistent nausea and no histologic evidence of GvHD in the stomach or duodenum

Persistent nausea with histologic evidence of GvHD in the stomach or duodenum
Diarrhea $<500 \mathrm{~mL} /$ day
Diarrhea $>500 \mathrm{~mL} /$ day
Diarrhea $>1000 \mathrm{~mL} /$ day
Diarrhea $>1500 \mathrm{~mL} /$ day

$\begin{array}{ll}\text { Diarrhea }<500 \mathrm{~mL} / \text { day } & \text { Diarrhea }<500 \mathrm{~mL} / \text { day } \\ \text { Diarrhea }>500 \mathrm{~mL} / \text { day } & \text { Diarrhea }>500 \mathrm{~mL} / \text { day } \\ \text { Diarrhea }>1000 \mathrm{~mL} / \text { day } & \text { Diarrhea }>1000 \mathrm{~mL} / \text { day } \\ \text { Diarrhea }>1500 \mathrm{~mL} / \text { day } & \text { Diarrhea }>1500 \mathrm{~mL} / \text { day }\end{array}$

Diarrhea $>2000 \mathrm{~mL} /$ day

Severe abdominal pain with or without ileus

No or intermittent ${ }^{\mathrm{a}}$ anorexia or nausea or vomiting

Persistent $^{\mathrm{a}}$ anorexia or nausea or vomiting

$$
\begin{aligned}
& \text { Diarrhea }<500 \mathrm{~mL} / \mathrm{day} \\
& \text { or }<3 \text { episodes/day for adults }{ }^{\mathrm{b}, \mathrm{c}} \\
& \text { Diarrhea 500-999 mL/day } \\
& \text { or 3-4 episodes/day for adults }{ }^{\mathrm{b}, \mathrm{d}} \\
& \text { Diarrhea 1000-1500 mL/day } \\
& \text { or 5-7 episodes/day for adults, } \\
& \text { Diarrhea }>1500 \mathrm{~mL} / \text { day } \\
& \text { or }>7 \text { episodes/day for adults }{ }^{\mathrm{b}, \mathrm{f}}
\end{aligned}
$$

Severe abdominal pain with or without ileus or grossly bloody stools (regardless of stool volume)
$>30 \%$
NA
NA
$<30 \%$
NA
NA

AST (Aspartate transaminase); BSA (Body surface area); GI (Gastro-intestinal tract); GvHD (Graft versus Host Disease); IBMTR (International Bone Marrow Transplantation Registry); IU (International units); MAGIC (Mount Sinai Acute GvHD International Consortium); NA (Not applicable); SGOT (Serum glutamic oxaloacetic acid transaminase)

a To be suggestive for GvHD: anorexia should be accompanied by weight loss, nausea should last at least 3 days, or be accompanied by at least 2 vomiting episodes per day for at least 2 days [16]

${ }^{\mathrm{b}}$ One episode of diarrhea is considered to be about $200 \mathrm{ml}$ for an adult and $3 \mathrm{ml} / \mathrm{kg}$ for a child $(<50 \mathrm{~kg})[16]$

${ }^{\mathrm{c}}$ Diarrhea $<10 \mathrm{~mL} / \mathrm{kg} /$ day or $<4$ episodes/day for children

${ }^{\mathrm{d}}$ Diarrhea $10-19.9 \mathrm{~mL} / \mathrm{kg} / \mathrm{day}$ or 4-6 episodes/day for children

${ }^{\mathrm{e}}$ Diarrhea $20-30 \mathrm{~mL} / \mathrm{kg} /$ day or $7-10$ episodes/day for children

${ }^{\mathrm{f}}$ Diarrhea $>30 \mathrm{~mL} / \mathrm{kg} /$ day or $>10$ episodes/day for children 
Table 2 Comparison of the different guidelines available for acute GvHD assessment: overall severity grading

\begin{tabular}{|c|c|c|c|c|c|}
\hline $\begin{array}{l}\text { overall } \\
\text { Glucksberg/ } \\
\text { MAGIC } \\
\text { grade }\end{array}$ & Original Glucksberg criteria [13] & $\begin{array}{l}\text { "Modified Glucksberg" or "Keystone" } \\
\text { criteria [14] }\end{array}$ & MAGIC criteria[16] & IBMTR criteria [15] & $\begin{array}{l}\text { overall } \\
\text { IBMTR } \\
\text { grade }\end{array}$ \\
\hline 0 & \multicolumn{4}{|c|}{ no organ involvement (skin $=0$; and liver $=0$; and $\mathrm{GI}=0$ ) corresponds to the absence of aGvHD } & 0 \\
\hline I & $\begin{array}{c}\text { skin }=1 \text { or } 2 \\
\text { without liver/GI involvement or } \\
\text { decrease in performance } \\
\text { status/fever }\end{array}$ & $\begin{array}{c}\text { skin }=1 \text { or } 2, \\
\text { without liver/GI } \\
\text { involvement }\end{array}$ & & $\begin{array}{c}\text { skin }=1, \\
\text { without liver/GI } \\
\text { involvement }\end{array}$ & A \\
\hline II & $\begin{array}{l}\text { skin }=1 \text { or } 2 \\
\text { and (liver and/or GI involvement }=1 \text { or } 2 \text { ) } \\
\text { with mild decrease in performance status }\end{array}$ & $\begin{array}{c}\text { skin }=3 \\
\text { and/or liver }=1 \\
\text { and/or } \mathrm{GI}=1\end{array}$ & & $\begin{array}{c}\text { skin }=2 ; \\
\text { and/or liver }=1 \text { or } 2 ; \\
\text { and/or } \mathrm{GI}=1 \text { or } 2\end{array}$ & B \\
\hline $\mathrm{III}^{\mathrm{a}}$ & $\begin{array}{c}\text { (skin and/or liver and/or } \\
\mathrm{GI}=2,3 \text { or } 4 \text { ) } \\
\text { with marked decrease in } \\
\text { performance status }\end{array}$ & $\begin{array}{c}\text { liver }=2 \text { or } 3 \\
\text { and/or } \mathrm{GI}=2,3 \text { or } 4^{\mathrm{a}}\end{array}$ & $\begin{array}{c}\text { liver }=2 \text { or } 3 \\
\text { and/or } \mathrm{GI}=2 \text { or } 3\end{array}$ & $\begin{array}{c}\text { skin }=3 ; \\
\text { and/or liver }=3 ; \\
\text { and/or GI }=3\end{array}$ & $\mathrm{C}$ \\
\hline $\mathrm{IV}^{\mathrm{b}}$ & $\begin{array}{l}\text { (skin and/or liver and/or } \\
\text { GI }=2,3 \text { or } 4 \text { ) } \\
\text { with Karnofsky }<30 \%\end{array}$ & $\begin{array}{c}\text { skin }=4 ; \\
\text { and/or liver }=4^{\mathrm{b}}\end{array}$ & $\begin{array}{r}\mathrm{s} \\
\text { and } / \\
\text { and }\end{array}$ & $\begin{array}{l}\mathrm{n}=4 \\
\text { liver }=4 \\
\mathrm{r} \mathrm{GI}=4\end{array}$ & $\mathrm{D}$ \\
\hline
\end{tabular}

The overall aGvHD grade typically corresponds to the highest grade conferred by the individual staging of each organ. GI (Gastro-intestinal tract); GvHD (Graft versus Host Disease); IBMTR (International Bone Marrow Transplantation Registry); MAGIC (Mount Sinai Acute GvHD International Consortium)

an the Minnesota criteria [19], overall grade III refers to liver $=2,3$ or 4 ; and/or GI $=2$ or 3

${ }^{\mathrm{b}}$ In the Minnesota criteria [19], overall grade IV refers to $\mathrm{skin}=4$; and/or GI $=4$

Specifically, stage 4 cutaneous involvement requires the presence of ulcerations or bullous formations on a minimum of $5 \%$ of the body surface area. Stage 4 lower GI aGvHD is also considered an overall grade of IV, better reflecting its dismal prognosis [20]. Guidance for the classification of GI involvement is given with thresholds for both upper GI (based on a minimum number of precisely defined symptoms, with or without a positive biopsy) and lower GI tract (based on the number of liquid stool episodes and/or average volume per episode) (Table 1). The MAGIC criteria are actively used by several international consortia (the BMT Clinical Trials Network and the Children's Oncology Group) and in biomarker development research. In the opinion of this panel, the MAGIC criteria are considered the most current and detailed criteria to diagnose and score the severity of aGvHD, especially for the clarity of what constitutes clinically significant upper GI symptoms and stage 4 skin and GI involvement. It should be noted that there is little difference anticipated between the MAGIC and modified Glucksberg criteria when grades III and IV are combined for analysis. The changes in the definition of upper GI GVHD could affect assignment to overall grades I or II.

Of note, the MAGIC group also introduced the concept of diagnostic confidence levels for acute GvHD: "confirmed", "probable", "possible" and "negative" correlating with histological confirmation, initiation of treatment, resolution without therapeutic intervention, and definitive alternative histologic diagnosis, respectively. Further prospective validation of the confidence categories is underway to formally assess their predictive value and reliability.

\section{Chronic GvHD definition}

Chronic GvHD was originally defined in the early 1980s in a cohort of 20 Seattle patients, as any GvHD present beyond day 100. cGvHD severity was categorized as "limited" (localized skin lesions with or without limited hepatic involvement) or "extensive" (generalized skin involvement, major hepatic complications, or involvement of any other organ) [21]. 20 years later, a survey of transplant professionals' responses to clinical cGvHD vignettes demonstrated wide variations in scoring practices [3] and led to a refinement of the original Seattle criteria (Table 3) [22].

In 2005, the first NIH "expert-opinion" consensus conference for cGvHD defined precise criteria for the diagnosis and staging of individual organ severity, based on functional disability, and eliminated the requirement that all GvHD occurring after day 100 be considered cGvHD [17]. The conference proposed that the diagnosis of cGvHD rely on either specific diagnostic signs or other distinctive signs accompanied by additional confirmation (e.g. biopsy or other objective diagnostic test) in at least one target organ (skin and appendages, mouth, eyes, genitalia, esophagus, lungs and muscles and fascia). The "overlap cGvHD subtype" was defined by the diagnosis of cGvHD together with acute GvHD manifestations of the skin, liver or gut (Fig. 1a). The severity of cGvHD (either classic or overlap) was scored by patient symptoms as well as functional organ impairment, ranging from 0 (absent) to 3 (severe) for each involved organ. A final global severity score for cGvHD is "mild" when a maximum of two organs are scored 1, 
Table 3 Comparison of the different guidelines available for chronic GvHD assessment: overall severity staging

Original Seattle criteria [21]

Revised Seattle criteria [22]

NIH criteria (2005 [17] and 2014

[18])

Diagnosis

NA

NA

\begin{abstract}
Based on either the presence of specific diagnostic signs or distinctive signs accompanied by additional confirmation (e.g. biopsy or other objective diagnostic test) in at least one target organ (skin \& appendages, mouth, eyes, genitalia, esophagus, lungs and muscles \& fascia)
\end{abstract}

\section{Severity Scoring}

Limited skin AND/OR limited hepatic

Limited involvement

Limited skin AND/OR limited hepatic involvement OR single organ sicca syndrome (eyes, mouth, vagina)

Generalized skin involvement AND/OR major Extensive hepatic complications AND/OR an isolated sicca syndrome of the eyes, mouth AND/OR any other organ involvement
Generalized skin involvement AND/OR major hepatic complications AND/OR multiple organs involved (more than two, including "nails"), the presence of skin sclerosis/serositis or fasciitis, bronchiolitis obliterans, decreased performance status $(<60 \%$ Karnofsky-Lansky index) or weight loss $>15 \%$
Mild No more than two organs with a score ${ }^{a}$ of 1 , except for lung

Moderate Any other severity scoring ${ }^{\mathrm{a}}$ not included in the mild or severe categories

Severe At least one organ with a score $^{\mathrm{a}}$ of 3 or a lung score $^{\mathrm{a}}$ of 2

GvHD graft versus host disease, $N A$ not applicable, $N I H$ National Institutes of Health

${ }^{a}$ Based on specific severity criteria described individually for the manifestations of chronic GvHD in eight target organs (skin \& appendages, mouth, eyes, genitalia, GI tract, liver, lungs and muscles \& fascia) and measured on a range of 0 (absent) to 3 (severe) for each organ [18]

"severe" if any organ is scored 3, and "moderate" for all other combinations. Lungs provide the single exception to this rule, where a lung score of 1 results in a global score of "moderate", and a lung score of 2 results in an overall "severe" score because of the potential irreversibility of pulmonary lesions and the poor prognosis for patients so affected [23, 24].

In 2014, a second NIH consensus conference revisited and updated these criteria based on the evidence generated during the intervening decade [18]. One major recommendation was to eliminate from the severity score any dysfunction unequivocally caused by an alternative etiology. Several further refinements to single organ staging were also recommended. In the opinion of this task force, the NIH 2014 criteria are the most accurate and widely accepted standard for the diagnosis and scoring of cGvHD.

\section{Issue 2: Application to clinical practice}

Because the above-mentioned guidelines were developed for research purposes, their application to "real-life" scenarios can be quite challenging for healthcare professionals.
This section offers guidance for the application of these international standards in clinical practice.

\section{Assessment of the global severity of GvHD}

The patient's global severity assessment (overall grade) evaluates exclusively three organs for aGvHD (skin, liver, and GI tract) and eight organs for cGvHD (skin, mouth, eyes, GI tract, liver, lungs, muscles/joints/fascia and genitals), based on the highest score of organ involvement as described above (Tables 2 and 3). No other abnormalities have an impact on the global severity scoring. The patient's functional status is documented by Karnofsky-Lansky scores, but it does not contribute to the overall score of either acute [14-16, 19] or chronic GvHD [17, 18]. Similarly, "undefined other" cGvHD manifestations or the "opinion of the evaluator" should be recorded but should not have an impact on the final global score [18].

\section{Multiple causes of organ impairment}

For both acute and chronic GvHD, a given organ is not considered in the overall GvHD grade if the manifestation is solely due to a non-GvHD cause (e.g. zoster skin infection, 
chronic obstructive pulmonary disease, steroid myopathy, etc...). In the case of both GvHD and concomitant nonGvHD etiologies, it is useful to document the non-GvHD causes but there is currently no justification to downgrade an organ score due to concurrent additional causes (e.g. simultaneous liver GvHD and veno-occlusive disease) $[18,25]$.

\section{Organ-specific issues}

Acute GvHD typically only involves three organs: the skin, the liver, and the GI tract [16]. Alloimmune manifestations in other organs are to be linked to chronic GvHD (Fig. 1a) [18]. For instance, oral GvHD with lichen planus-like changes is always considered to be a chronic manifestation even if it appears in the early post-transplantation phase (where it needs to be differentiated from alternative etiologies). Obstructive lung manifestations are also always considered to be chronic features, provided they are either confirmed by biopsy or meet strict diagnostic criteria and are accompanied by at least one diagnostic or distinctive manifestation of cGvHD elsewhere [18].

Some patients have atypical signs and symptoms that might be considered cGvHD but fall outside of the current diagnostic, staging and response criteria $[18,27]$. Such manifestations of potential alloreactivity (e.g. ascites, serositis, nephrotic syndrome, membranous glomerulopathy, myasthenia gravis, peripheral neuropathy, polymyositis, weight loss in the absence of GI symptoms, Raynaud's phenomenon, cardiac involvement, eosinophilia, decreased platelet counts, thyroid disorders, etc...) [18] can occur at any time after transplantation. If attributed by the treating physician to cGvHD, they should be categorized as "undefined other cGvHD" (Fig. 1a). This category may represent $10-15 \%$ of patients (Kirk Shultz, personal communication). Capturing these data in prospective cohorts is recommended to understand the full spectrum and true incidence of immunological complications after HCT, especially when such manifestations drive management decisions (e.g. the treating physician alters immunosuppression suspecting a link with cGvHD). All manifestations treated as cGvHD should thus be documented, irrespective of whether they meet NIH diagnostic criteria, provided that their "undefined other" nature is clearly noted.

Similarly, isolated increase of transaminases is relatively common during the taper of immunosuppression or after donor lymphocyte infusions. This increase should also be assigned to the "undefined other cGvHD" group, provided it is treated as GvHD in the absence of meeting NIH diagnostic criteria and no histopathological confirmation of liver GvHD has been obtained. Because of their invasive character, liver biopsies are rarely performed and the nature of hepatic enzyme disturbances remains therefore uncertain. This further emphasizes the need for prospective recording of such abnormalities [28].

\section{Overlap chronic GvHD}

Overlap cGvHD is a subtype of cGvHD which has been associated with a poor prognosis $[29,30]$. It is characterized by the simultaneous presence of acute and chronic GvHD features (Fig. 1a). Chronic GvHD that is accompanied by acute GI manifestations (anorexia, nausea, vomiting, diarrhea, severe abdominal pain, GI bleeding, and/or ileus) is categorized as overlap cGvHD [17, 18]. However, skin manifestations of aGvHD (maculopapular erythematous rash) can be difficult to differentiate from those of cGvHD. Similarly, the elevation of bilirubin (often accompanied by elevated hepatic enzymes) suggests involvement of the liver, but cannot be unequivocally attributable to either an acute or a chronic process. Given these uncertainties, we currently recommend systematic documentation of aGvHD manifestations (in any organ) and subclassification of such cases as overlap cGvHD, while awaiting future "biologybased" classifications.

\section{Specific guidance for the assessment of chronic GvHD}

\section{Skin, muscle, and fascia involvement}

In cGvHD, MRI can sometimes be a useful tool to detect fascia involvement [31], yet distinguishing between skin and muscle/fascia fibrosis as the cause of functional impairment is frequently challenging. Once movement is impaired, muscles and fascia are generally involved and are almost always associated with sclerotic skin GvHD [32]. Therefore, skin and fascia involvement should then be documented, even if skin involvement is the primary manifestation. Furthermore, although photographic-range of motion (P-ROM) ratings have been recognized as a sensitive way to capture fascia involvement and response to treatment [33], they cannot be directly translated into severity scores of joints-fascia involvement [18]. Finally, muscle cramps are frequently reported by GvHD patients but are not specific and are not included in the severity score.

\section{Scheduling pulmonary function tests and genital exams}

Clinical practice rarely allows time and resources for an exhaustive patient evaluation of cGvHD at every visit. For example, pulmonary function tests (PFTs) and genital examinations typically require third-party input, which can be challenging to obtain on the same day. 
Table 4 Suggested definitions for commonly used GvHD terminology

\begin{tabular}{|c|c|c|c|}
\hline \multicolumn{4}{|c|}{ Acute and chronic GvHD status } \\
\hline Clinical GvHD status & $\begin{array}{l}\text { Acute or chronic GvHD inflammatory } \\
\text { or worsening manifestations }\end{array}$ & GvHD sequelae ${ }^{a}$ & Systemic immunosuppressive treatment \\
\hline Active & Present & Irrelevant & Irrelevant \\
\hline Controlled & Absent & Irrelevant & $\begin{array}{l}\text { On immunosuppression } \\
\text { or immunosuppression stopped for }<12^{\mathrm{b}} \text { to } 24^{\mathrm{c}} \text { weeks }\end{array}$ \\
\hline Inactive & Absent & Present & $\begin{array}{l}\text { Off immunosuppression } \\
\text { (immunosuppression stopped for }>12^{\mathrm{b}} \text { to } 24^{\mathrm{c}} \text { weeks) }\end{array}$ \\
\hline Resolved & Absent & Absent & $\begin{array}{l}\text { Off immunosuppression } \\
\text { (immunosuppression stopped for }>12^{\mathrm{b}} \text { to } 24^{\mathrm{c}} \text { weeks) }\end{array}$ \\
\hline
\end{tabular}

\section{Acute and chronic GvHD onset}

\begin{tabular}{|c|c|c|}
\hline \multicolumn{2}{|l|}{ aGvHD onset } & \multirow{2}{*}{$\frac{\text { Timing post HCT or DLI }}{\leq \text { Day } 100}$} \\
\hline Classic & First episode of aGvHD ${ }^{\mathrm{d}}$ & \\
\hline Late & First episode of aGvHD ${ }^{d}$ & $>$ Day 100 \\
\hline Recurrent & Recurrence of aGvHD ${ }^{\mathrm{d}}$, after a period of aGvHD control, inactivity or resolution & $>$ Day 100 \\
\hline Persistent & $\mathrm{aGvHD}^{\mathrm{d}}$ signs persist beyond day 100 from a prior active classic aGvHD & $>$ Day 100 \\
\hline cGvHD onset & & Timing post HCT or DLI \\
\hline De novo & First episode of cGvHD, without prior aGVHD & Irrelevant \\
\hline Quiescent & Development of cGvHD, after a period of aGvHD control, inactivity or resolution & Irrelevant \\
\hline Progressive & First episode of cGvHD, while aGvHD symptoms are still active & Irrelevant \\
\hline
\end{tabular}

\begin{tabular}{lll}
\hline & Acute GvHD steroid response & Chronic GvHD steroid response \\
\hline $\begin{array}{l}\text { Steroid } \\
\text { refractoriness } \\
\text { or resistance }\end{array}$ & $\begin{array}{l}\text { Progression of aGvHD within 3-5 days of therapy onset cGvHD progression while on prednisone at } \geq 1 \mathrm{mg} / \mathrm{kg} / \mathrm{day} \text { for } 1 \\
\text { with } \geq 2 \mathrm{mg} / \mathrm{kg} / \mathrm{day} \text { of prednisone } \\
\text { OR failure to improve within 5-7 days of treatment } \\
\text { initiation } \\
\text { OR incomplete response after more than 28 days of } \\
\text { immunosuppressive treatment including steroids }\end{array}$ & $\begin{array}{l}\text { OR stable GvHD disease while on } \geq 0.5 \mathrm{mg} / \mathrm{kg} / \mathrm{day}{ }^{\mathrm{e}} \text { of prednisone } \\
\text { for } 1-2 \text { months }\end{array}$ \\
$\begin{array}{l}\text { Steroid } \\
\text { Iependence } \\
\text { Steroid } \\
\text { intolerance }\end{array}$ & $\begin{array}{l}\text { OR a recurrence of aGvHD activity during steroid taper } \\
\text { Inability to taper prednisone below } 0.25 \mathrm{mg} / \mathrm{kg} / \mathrm{day}{ }^{\mathrm{f}} \text { in at least two }\end{array}$ \\
\hline
\end{tabular}

$D L I$ donor lymphocyte infusion, $H C T$ hematopoietic cell transplantation, $G v H D$ graft versus host disease

${ }^{a}$ GvHD irreversible scars or fixed deficits

${ }^{\mathrm{b}}$ For acute GvHD

${ }^{\mathrm{c}}$ For chronic GvHD

${ }^{\mathrm{d}}$ Presenting acute features only: maculopapular erythematous skin rash; and/or hyperbilirubinemia; and/or anorexia with weight loss, nausea, vomiting, diarrhea, severe abdominal pain, GI bleeding and/or ileus [16]

${ }^{\text {e }}$ Or $1 \mathrm{mg} / \mathrm{kg}$ every other day

${ }^{\mathrm{f}}$ Or $>0.5 \mathrm{mg} / \mathrm{kg}$ every other day

Although both the dyspnea and lung function scores should ideally be recorded, PFTs are the best way to describe lung involvement and should be obtained at diagnosis of GvHD and then minimally every 3-6 months thereafter in patients on systemic therapy for active cGvHD $[34,35]$. However, if recent (maximum 3-6 months old) PFTs are missing, we recommend that symptomatic dyspnea score be used for scoring [18] until updated PFTs are available. Documentation should ideally allow tracing of which source of information (symptoms or PFTs) was used, to allow for meaningful comparisons over time.

A formal genital exam or inspection should ideally be performed at diagnosis and at every GvHD evaluation thereafter in patients with active cGvHD. In clinical practice, this is not always feasible; therefore, we recommend this exam be performed within 3 months of cGvHD 
diagnosis followed by a regular follow-up every $9-12$ months $[35,36]$. At other time points, a genital exam is recommended when a patient reports specific discomfort or new lesions in the genital area.

Of note, both pulmonary and urogenital complications can go undetected if not specifically queried, with potentially dramatic clinical consequences [23, 24, 37-39]. Patients should be asked about symptoms and functional impairments at every visit, since early recognition of these complications can often be addressed with relatively simple therapeutic measures, including local or limited systemic immunosuppressive treatment [36, 40, 41].

\section{Controversies in chronic GvHD}

In spite of the extensive harmonization effort of the cGvHD NIH consortium, some criteria would benefit from further clarification. For instance, weight loss is categorized based on the percentage decrease of bodyweight occurring over a 3 -month period [18]. It is unclear how to classify patients who lose a significant amount of weight initially but have stabilized by the time of evaluation. For now, we recommend to limit the impact of weight loss on severity scoring to the last 3 months preceding the GvHD assessment time point. Another controversial issue is the use of therapeutic measures to define severity (e.g. the placement of punctal plugs for severely dry eyes [18, 27], the use of specific eye ware to relieve pain [18, 27] or the dilatation of esophageal stenosis [18]). Given the lack of empirical data, clarification of these issues will require consensus and validation efforts in the future. In the meantime, we recommend to track therapeutic interventions and specify in clinical protocols and/or standard operating procedures whether the severity score considers treatments/procedures ever received or within a specific timeframe.

\section{Pediatric considerations}

Three primary areas differ in the pediatric population with regards to GvHD assessment: (1) some criteria used in adults are difficult to apply in young children (e.g. PFTs and Schirmer's test for children under the age of 6 [18]); (2) the incidence of cGvHD appears lower in children [42, 43]; and (3) approximately $50 \%$ of pediatric transplants are performed for nonmalignant disorders, where tissue repair defects that may impact development of GvHD are more common (e.g. increase of aGvHD in Fanconi Anemia patients [44]).

Currently, the only organs with specific pediatric modifications recommendations for GvHD assessment are: (1) adapted body surface area maps for skin involvement; (2) appropriate reference values for lung function; and (3) weight-adapted measures for diarrhea [16, 18]. Moreover, as PFTs are unreliable for children under the age of 6 years, diagnosis and scoring of lung GvHD relies instead on clinical evaluation, imaging, and lung biopsy [18]. The high frequency of usually transient viral erythema, which can be mistaken for manifestations of aGvHD, is another issue in children. There is thus clearly an unmet need for developing pediatric population-adapted GvHD symptom scales and assessments [45].

\section{Issue 3: A standardized GvHD terminology}

In clinical practice, GvHD presentations can range from a rapidly progressive extensive inflammatory syndrome requiring immediate and aggressive systemic immune suppression, to purely fibrotic, cicatricial manifestations with fixed deficits that are unlikely to respond quickly or completely resolve with therapy [26]. Between these extremes, the large spectrum of presentations, occurring in the context of a wide variety in GvHD prevention and treatment regimens, is more challenging to describe. Many of the terms frequently used to communicate with patients and colleagues lack clear, broadly accepted definitions. We propose here several definitions for a standardized GvHD terminology in order to facilitate future research and allow more accurate comparisons among studies (Table 4).

\section{GvHD activity}

In the setting of clinical trials, response to treatment compares disease burden at specific points in time, usually with regards to a particular treatment. It is based on a number of clinical findings, sometimes including fixed deficits. Classical categories of response are complete response (CR), partial response (PR), and lack of response (which includes no change, mixed response and progression), as established by the NIH consortium for chronic GvHD [27]. For acute GvHD, similar criteria have been described by the MAGIC consortium [46].

However, GvHD activity may be distinct from response if the disease burden includes fixed deficits that are no longer responsive to treatment. Identification of such deficits can be difficult but is essential to the accurate description of complex clinical phenotypes, particularly in cGvHD. Determination of GvHD activity is often the principal driver in therapeutic decisions (e.g. intensification, reduction (taper) or discontinuation of immunosuppression) and is likely to be critical for biomarker validation. We therefore propose a classification of GvHD activity that incorporates both the presence of disease manifestations and the use of immunosuppression, consistent with the NIH Consensus task force model of GvHD physiopathology [26]. 
GvHD is considered "clinically active" if the patient has inflammatory or worsening manifestations (either acute or chronic) regardless of the use of immunosuppressive therapy. After the inflammation resolves, GvHD manifestations can either disappear without residua or fixed deficits may remain. Such fixed or irreversible deficits represent scars in the affected organ due to either permanent damage or aberrant tissue repair (e.g. skin color change, stable fibrotic features, sicca syndrome) that persist regardless of immunosuppressive treatment [26].

Once all signs of clinical activity have disappeared, GvHD activity can be described in three different ways. If immunosuppression is still ongoing or has been discontinued for less than 12 weeks [26] or 24 weeks [47] for acute and chronic GvHD respectively, GvHD activity can be considered "controlled" regardless of the presence of fixed sequelae. If immunosuppression has been discontinued for more than the above mentionned periods of time without recurrence of inflammatory signs, GvHD is termed "resolved" if there are no fixed deficits and "inactive" if such fixed deficits persist.

\section{GvHD onset}

GvHD onset refers to the presentation of the first episode of clinically evident alloreactivity of the donor against the recipient host (Fig. 1b, c).

"Classic acute GvHD" refers to the initial diagnosis of acute GvHD within the first 100 days following transplantation or DLI infusion (whichever happened last) [17]. "Late acute GvHD" occurs beyond day 100 and can be: "late onset" (new onset of aGvHD with no prior history of classic aGvHD), "recurrent onset" (recurrence of aGvHD in a patient with prior history of classic aGvHD whose symptoms became controlled, inactive or resolved); or "persistent" if active aGvHD signs persist beyond day 100 in the absence of cGvHD manifestations [17].

Chronic GvHD is referred to as having "de novo onset" if cGvHD is diagnosed [18] for the first time in a patient who did not previously experience acute GvHD [17, 18]. "Quiescent onset" is defined as cGvHD that appears for the first time after all acute GvHD manifestations have become controlled, inactive or resolved [17, 18]. "Progressive onset" refers exclusively to the initial presentation of cGvHD manifestations while acute GvHD symptoms are still active [17, 18]. It is therefore always a form of overlap cGvHD (Fig. 1a), although not all overlap cGvHD syndromes present with a progressive onset. "Progressive onset" is also distinct from "progression", which is a response criterion that refers to an increase in severity of acute or chronic GvHD symptoms over time [27, 46]. "Progressive onset" cGvHD has been associated for over 30 years with inferior prognosis and poor response to treatment
[48-60]. Yet, it should be noted that because these studies used a variety of definitions, some patients, who did not present with new cGvHD manifestations, would now be reclassified as "persistent late acute GvHD". Interestingly, Stewart et al. showed that after the dose of prednisone was taken into account, "progressive onset" no longer predicted long-term survival [60], suggesting that the level of chronic immunosuppression at diagnosis influences the prognosis for cGvHD with this type of onset.

There is currently no formal nomenclature to refer to the pattern of GvHD recurrence after an initial diagnosis. The term "flare" is sometimes used to define the reappearance or worsening of any signs of GvHD. Although this might reflect the natural course of the disease, this term currently lacks a validated definition. For written scientific communications, we recommend instead the precise terminology that refers to disease onset [17] or the classical clinical trial response criteria [27], as appropriate.

\section{Response to steroids}

Acute GvHD steroid refractoriness or resistance is most often referred to as either (1) progression in any organ within 3 [61-71], 4 [72-76], or 5 [77-79] days of therapy onset with $\geq 2 \mathrm{mg} / \mathrm{kg} /$ day $[61-63,69-71,73,74,76-78,80-84]$ of prednisone equivalent, (2) failure to improve within 5 [67] to 7 [61, 62, 64-66, 68, 69, 72, 74-76, 78, 80, 81, 83] days of treatment initiation $[71,79,85]$ or (3) incomplete response after more than 28 days of immunosuppressive treatment including steroids [46]. For the determination of eligibility in prospective clinical trials, alternative definitions for aGvHD steroid refractoriness may include other aspects such as: incomplete response after 14 days of therapy [64-66, 75, 78, $79,86]$ or use of an additional immunosuppressive agent [86]. Chronic GvHD steroid refractoriness or resistance is typically referred to as either: (1) progression of GvHD while on prednisone at $\geq 1 \mathrm{mg} / \mathrm{kg} / \mathrm{day}$ for 1 [87] to 2 [88] weeks; or (2) stable GvHD on $\geq 0.5 \mathrm{mg} / \mathrm{kg} /$ day (or $1 \mathrm{mg} / \mathrm{kg}$ every other day) of prednisone for 1 [87, 89] to 2 months $[65,88]$.

Steroid dependence has been defined for aGvHD as the inability to taper prednisone under $2 \mathrm{mg} / \mathrm{kg} /$ day after an initially successful treatment of at least 7 days [74, 80, 81] or as the recurrence of aGvHD activity during steroid taper [68, 79]. The relevance of this term was shown by Martin and colleagues who demonstrated that the highest $\mathrm{CR}$ rates with secondary therapy were seen when aGvHD recurred during the taper phase of the primary glucocorticoid treatment, thereby distinguishing it from steroid refractory aGvHD [90]. In $\mathrm{cGvHD}$, steroid dependence refers to the inability to control GvHD symptoms while tapering prednisone below $0.25 \mathrm{mg} / \mathrm{kg} /$ day (or $0.5 \mathrm{mg} / \mathrm{kg}$ every other day) in at least two individual attempts, separated by at least 8 weeks [87]. 
Finally, the term "steroid intolerance" has not been formally validated but refers to the emergence of unacceptable toxicity (e.g. uncontrolled infections, avascular necrosis, arterial hypertension, diabetes mellitus, myopathy, osteoporosis, etc.) attributed to corticosteroids, as evaluated by a healthcare professional $[91,92]$.

\section{Conclusions}

This report stresses the critical importance of a common, international approach to describe the variety of GvHD clinical manifestations observed after HCT. In the era of electronic patient records and e-health applications, it is possible to apply complex algorithms at the bedside and follow internationally vetted guidelines in daily clinical practice. Several efforts in this direction [4, 9-12], such as the eGVHD app (available at https://www.uzleuven.be/egvhd), are already developing more standardized and accurate methods to capture "real-world" GvHD data. This progress underlines the responsibility of transplantation societies to help clarify definitions, to facilitate comparisons of clinical research results and to set standards for clinical practice.

This task force panel advocates the use of the MAGIC criteria for aGvHD and the NIH 2014 criteria for cGvHD as the most comprehensive and detailed criteria currently available. In addition, this statement provides consensus definitions for a lexicon of commonly used GvHD terms and concepts in order to facilitate GvHD clinical research.

The standardization of GvHD assessments should be a dynamic process that can incorporate progress in new diagnostic and therapeutic approaches. Even as refined classifications improve communication among clinicians, they should also be prospectively evaluated for their predictive potential. Furthermore, in the absence of any pathognomonic signs or test for GvHD, subjective elements remain an integral part of the final clinical assessment. As prospective biomarkers that detect underlying GvHD pathophysiology are validated, they may assist clinicians by offering objective laboratory metrics in addition to clinical GvHD manifestations. But the formal validation of these markers requires accurate and reliable clinical assessment of GvHD severity in all organs.

We hope that this position statement will serve as the cornerstone of a larger scale consensus project. Consistent adherence to common sets of criteria, such as those endorsed here, will help the transplantation community to improve the quality of data capture across all types of GvHD manifestations and therapeutic strategies. Harmonization of standards for the accurate assessment of GvHD is an essential prerequisite for the formulation of recommendations $[85,93]$ regarding GvHD prophylaxis and treatment that are based on quality evidence.

\section{Disclaimer}

The opinions expressed here are those of the authors and do not represent the official position of the NIH, NCI, or the United States Government.

Acknowledgements The authors would like to acknowledge the support of the Association for Training, Education, and Research in Hematology, Immunology, and Transplantation (ATERHIT) and for facilitating dissemination of this article through providing open access.

Author contributions HMS coordinated the project, performed the research and wrote the manuscript. All authors (HMS, SJL, JLF, DW, JEL, KRS, BES, MEF, TR, HG, EH, GB, RFD and SZP) participated in expert discussions. SJL, JLF, DW, JEL, and BES iteratively reviewed the manuscript. RFD and SZP designed the research, performed the research and wrote the manuscript. All authors reviewed the final version and approved submission.

\section{Compliance with ethical standards}

Conflict of interest The authors declare that they have no conflict of interest.

Open Access This article is licensed under a Creative Commons Attribution 4.0 International License, which permits use, sharing, adaptation, distribution and reproduction in any medium or format, as long as you give appropriate credit to the original author(s) and the source, provide a link to the Creative Commons license, and indicate if changes were made. The images or other third party material in this article are included in the article's Creative Commons license, unless indicated otherwise in a credit line to the material. If material is not included in the article's Creative Commons license and your intended use is not permitted by statutory regulation or exceeds the permitted use, you will need to obtain permission directly from the copyright holder. To view a copy of this license, visit http://creativecommons. org/licenses/by/4.0/.

\section{References}

1. WHO guiding principles on Human Cell, Tissue and Organ Transplantation. http://www.who.int/transplantation/Guiding PrinciplesTransplantation_WHA63.22en.pdf?ua $=1$ accessed Jan 8th 2018

2. Atkinson K, Horowitz MM, Biggs JC, Gale RP, Rimm AA, Bortin MM. The clinical diagnosis of acute graft-versus-host disease: a diversity of views amongst marrow transplant centers. Bone Marrow Transplant. 1988;3:5-10. e-pub ahead of print 1988/01/01

3. Lee SJ, Vogelsang G, Gilman A, Weisdorf DJ, Pavletic S, Antin $\mathrm{JH}$, et al. A survey of diagnosis, management, and grading of chronic GVHD. Biol Blood Marrow Transplant: J Am Soc Blood Marrow Transplant. 2002;8:32-39. e-pub ahead of print 2002/02/ 16

4. Schoemans H, Goris K, Durm RV, Vanhoof J, Wolff D, Greinix H, et al. Development, preliminary usability and accuracy testing of the EBMT 'eGVHD App' to support GvHD assessment according to NIH criteria-a proof of concept. Bone Marrow Transplant. 2016;51:1062-65. https://doi.org/10.1038/bmt.2016.26

5. Duarte RF, Greinix H, Rabin B, Mitchell SA, Basak G, Wolff D, et al. Uptake and use of recommendations for the diagnosis, severity scoring and management of chronic GVHD: an 
international survey of the EBMT-NCI Chronic GVHD Task Force. Bone Marrow Transplant. 2014;49:49-54. https://doi.org/ 10.1038/bmt.2013.129

6. Mitchell SA, Jacobsohn D, Thormann Powers KE, Carpenter PA, Flowers ME, Cowen EW, et al. A multicenter pilot evaluation of the National Institutes of Health chronic graft-versus-host disease (cGVHD) therapeutic response measures: feasibility, interrater reliability, and minimum detectable change. Biol Blood Marrow Transplant: J Am Soc Blood Marrow Transplant. 2011;17:19-1629. https://doi.org/10.1016/j.bbmt.2011.04.002. e-pub ahead of print 2011/05/04

7. Weisdorf DJ, Hurd D, Carter S, Howe C, Jensen LA, Wagner J, et al. Prospective grading of graft-versus-host disease after unrelated donor marrow transplantation: a grading algorithm versus blinded expert panel review. Biol Blood Marrow Transplant: J Am Soc Blood Marrow Transplant. 2003;9:512-8. e-pub ahead of print 2003/08/22

8. Carpenter PA, Logan BR, Lee SJ, Weisdorf DJ, Johnston L, Costa LJ, et al. Prednisone (PDN)/Sirolimus (SRL) compared to PDN/ $\mathrm{SRL} /$ calcineurin inhibitor (CNI) as treatment for chronic graftversus-host-disease (cGVHD): a randomized phase II study from the Blood and Marrow Transplant Clinical Trials Network. Biol Blood Marrow Transplant. 2016; 22:S50-S52. https://doi.org/10. 1016/j.bbmt.2015.11.336

9. Schoemans H, Goris K, Van Durm R, Vanbrabant K, De Geest S, Maertens J, et al. Accuracy and usability of the eGVHD app in assessing the severity of graft versus host disease at the 2017 EBMT Annual Congress. Bone Marrow Transplant. 2018 Apr;53 (4):490-494. https://doi.org/10.1038/s41409-017-0017-0

10. Levine JE, Hogan WJ, Harris AC, Litzow MR, Efebera YA, Devine SM, et al. Improved accuracy of acute graft-versus-host disease staging among multiple centers. Best Pract Res Clin Haematol. 2014;27:283-7. https://doi.org/10.1016/j.beha.2014. 10.011

11. Dierov Djamilia CC, Fatmi S, Mosesso K, Nieves J, Prockop S, Perales M-A, el al. Establishing a standardized system to capture chronic graft-versus-host disease (GVHD) data in accordance to the national institutes (NIH) consensus criteria. Bone Marrow Transplant. 2017;52(Suppl 1):S102. (abstract O157)

12. Mancini G, Frulla R, Vico M, Marinelli M, Olivieri J, Calandrelli $\mathrm{M}$, et al. A new software for evaluating scoring and response in cGVHD according to the new NIH criteria. Bone Marrow Transplant. 2016;51(Issue S1):S183.

13. Glucksberg H, Storb R, Fefer A, Buckner CD, Neiman PE, Clift $\mathrm{RA}$, et al. Clinical manifestations of graft-versus-host disease in human recipients of marrow from HL-A-matched sibling donors. Transplantation. 1974;18:295-304.

14. Przepiorka D, Weisdorf D, Martin P, Klingemann HG, Beatty P, Hows J, et al. 1994 consensus conference on acute GVHD grading. Bone Marrow Transplant. 1995;15:825-8. e-pub ahead of print 1995/06/01

15. Rowlings PA, Przepiorka D, Klein JP, Gale RP, Passweg JR, Henslee-Downey PJ, et al. IBMTR Severity Index for grading acute graft-versus-host disease: retrospective comparison with Glucksberg grade. Br J Haematol. 1997;97:855-64.

16. Harris AC, Young R, Devine S, Hogan WJ, Ayuk F, Bunworasate $\mathrm{U}$, et al. International, multicenter standardization of acute graft-versus-host disease clinical data collection: a report from the Mount Sinai Acute GVHD International Consortium. Biol Blood Marrow Transplant: J Am Soc Blood Marrow Transplant. 2016;22:4-10. https://doi.org/10.1016/j.bbmt. 2015.09.001

17. Filipovich AH, Weisdorf D, Pavletic S, Socie G, Wingard JR, Lee SJ, et al. National Institutes of Health consensus development project on criteria for clinical trials in chronic graft-versus-host disease: I. Diagnosis and staging working group report. Biol
Blood Marrow Transplant: J Am Soc Blood Marrow Transplant. 2005;11:945-56. https://doi.org/10.1016/j.bbmt.2005.09.004

18. Jagasia MH, Greinix HT, Arora M, Williams KM, Wolff D, Cowen EW, et al. National Institutes of Health Consensus Development Project on Criteria for Clinical Trials in Chronic Graft-versus-Host Disease: I. The 2014 Diagnosis and Staging Working Group report. Biol Blood Marrow Transplant: J Am Soc Blood Marrow Transplant. 2015;21:389-401. https://doi.org/10. 1016/j.bbmt.2014.12.001. e381

19. MacMillan ML, Weisdorf DJ, Wagner JE, DeFor TE, Burns LJ, Ramsay NK, et al. Response of 443 patients to steroids as primary therapy for acute graft-versus-host disease: comparison of grading systems. Biol Blood Marrow Transplant: J Am Soc Blood Marrow Transplant. 2002;8:387-94. e-pub ahead of print 2002/08/13

20. Castilla-Llorente C, Martin PJ, McDonald GB, Storer BE, Appelbaum FR, Deeg HJ, et al. Prognostic factors and outcomes of severe gastrointestinal GVHD after allogeneic hematopoietic cell transplantation. Bone Marrow Transplant. 2014;49:966-71. https://doi.org/10.1038/bmt.2014.69

21. Shulman HM, Sullivan KM, Weiden PL, McDonald GB, Striker GE, Sale GE, et al. Chronic graft-versus-host syndrome in man. A long-term clinicopathologic study of 20 Seattle patients. Am J Med. 1980;69:204-17.

22. Lee SJ, Vogelsang G, Flowers ME. Chronic graft-versus-host disease. Biol Blood Marrow Transplant: J Am Soc Blood Marrow Transplant. 2003;9:215-33. https://doi.org/10.1053/bbmt.2003. 50026

23. Palmer J, Williams K, Inamoto Y, Chai X, Martin PJ, Tomas LS, et al. Pulmonary symptoms measured by the national institutes of health lung score predict overall survival, nonrelapse mortality, and patient-reported outcomes in chronic graft-versus-host disease. Biol Blood Marrow Transplant: J Am Soc Blood Marrow Transplant. 2014;20:337-44. https://doi.org/10.1016/j.bbmt.2013. 11.025

24. Abedin S, Yanik GA, Braun T, Pawarode A, Magenau J, Goldstein SC, et al. Predictive value of bronchiolitis obliterans syndrome stage $0 \mathrm{p}$ in chronic graft-versus-host disease of the lung. Biol Blood Marrow Transplant: J Am Soc Blood Marrow Transplant. 2015;21:1127-31. https://doi.org/10.1016/j.bbmt. 2015.02.006

25. Goyal RK, Goyal M, Sankaranarayan K. Grading acute graftversus-host disease: time to reconsider. Pediatr Transplant. 2015;19:252-4. https://doi.org/10.1111/petr.12433

26. Cooke KR, Luznik L, Sarantopoulos S, Hakim FT, Jagasia M, Fowler DH, et al. The biology of chronic graft-versus-host disease: a Task Force Report from the National Institutes of Health Consensus Development Project on Criteria for Clinical Trials in Chronic Graft-versus-Host Disease. Biol Blood Marrow Transplant: J Am Soc Blood Marrow Transplant. 2017;23:211-34. https://doi.org/10.1016/j.bbmt.2016.09.023. e-pub ahead of print 2016/10/08

27. Lee SJ, Wolff D, Kitko C, Koreth J, Inamoto Y, Jagasia M, et al. Measuring therapeutic response in chronic graft-versus-host disease. National Institutes of Health consensus development project on criteria for clinical trials in chronic graft-versus-host disease: IV. The 2014 Response Criteria Working Group report. Biol Blood Marrow Transplant: J Am Soc Blood Marrow Transplant. 2015;21:984-99. https://doi.org/10.1016/j.bbmt.2015.02.025. epub ahead of print 2015/03/23

28. Stift J, Baba HA, Huber E, Federmann B, Fischer HP, SchmittGraeff A, et al. Consensus on the histopathological evaluation of liver biopsies from patients following allogeneic hematopoietic cell transplantation. Virchows Arch. 2014;464:175-90. https://doi. org/10.1007/s00428-013-1528-8

29. Moon JH, Sohn SK, Lambie A, Ellis L, Hamad N, Uhm J, et al. Validation of National Institutes of Health global scoring system 
for chronic graft-versus-host disease (GVHD) according to overall and GVHD-specific survival. Biol Blood Marrow Transplant: J Am Soc Blood Marrow Transplant. 2014;20:556-63. https://doi. org/10.1016/j.bbmt.2014.01.010. e-pub ahead of print 2014/01/23

30. Pidala J, Vogelsang G, Martin P, Chai X, Storer B, Pavletic S, et al. Overlap subtype of chronic graft-versus-host disease is associated with an adverse prognosis, functional impairment, and inferior patient-reported outcomes: a Chronic Graft-versus-Host Disease Consortium study. Haematologica. 2012;97:451-8. https://doi.org/10.3324/haematol.2011.055186. e-pub ahead of print 2011/11/08

31. Oda K, Nakaseko C, Ozawa S, Nishimura M, Saito Y, Yoshiba F, et al. Fasciitis and myositis: an analysis of muscle-related complications caused by chronic GVHD after allo-SCT. Bone Marrow Transplant. 2009;43:159-167. https://doi.org/10.1038/bmt.2008. 297. e-pub ahead of print 2008/09/03

32. Kuzmina Z, Joe GO, Baird K, Cowen EW, Naik HB, Steinberg $\mathrm{SM}$, et al. Prevalence of isolated joint involvement in chronic graft-versus-host disease: comment on the article by Inamoto et al. Arthritis \& Rheumatol (Hoboken, NJ). 2014;66:2646-48. https:// doi.org/10.1002/art.38697

33. Inamoto Y, Pidala J, Chai X, Kurland BF, Weisdorf D, Flowers $\mathrm{ME}$, et al. Assessment of joint and fascia manifestations in chronic graft-versus-host disease. Arthritis \& Rheumatol (Hoboken, NJ). 2014;66:1044-52. https://doi.org/10.1002/art.38293. e-pub ahead of print 2014/04/24

34. Hildebrandt GC, Fazekas T, Lawitschka A, Bertz H, Greinix H, Halter J, et al. Diagnosis and treatment of pulmonary chronic GVHD: report from the consensus conference on clinical practice in chronic GVHD. Bone Marrow Transplant. 2011;46:1283-95. https://doi.org/ 10.1038/bmt.2011.35. e-pub ahead of print 2011/03/29

35. Carpenter PA, Kitko CL, Elad S, Flowers ME, Gea-Banacloche JC, Halter JP, et al. National Institutes of Health Consensus Development Project on Criteria for Clinical Trials in Chronic Graft-versus-Host Disease: V. The 2014 Ancillary Therapy and Supportive Care Working Group Report. Biol Blood Marrow Transplant: J Am Soc Blood Marrow Transplant. 2015;21:1167-87. https://doi.org/10.1016/j.bbmt.2015.03.024

36. Frey Tirri B, Hausermann P, Bertz H, Greinix H, Lawitschka A, Schwarze CP, et al. Clinical guidelines for gynecologic care after hematopoietic SCT. Report from the international consensus project on clinical practice in chronic GVHD. Bone Marrow Transplant. 2015;50:3-9. https://doi.org/10.1038/bmt.2014.242. e-pub ahead of print 2014/10/28

37. Jain NA, Venkatesan K, Anandi P, Ito S, Kumar D, Lu K et al. A rare consequence of chronic graft versus host disease-Peyronie's disease. Arch Cancer Res 2015;3:18. e-pub ahead of print 2016/01/16.

38. Hirsch P, Leclerc M, Rybojad M, Petropoulou AD, Robin M, Ribaud $\mathrm{P}$, et al. Female genital chronic graft-versus-host disease: importance of early diagnosis to avoid severe complications. Transplantation 2012;93:1265-9. https://doi.org/10.1097/TP. 0b013e31824f3dcd. e-pub ahead of print 2012/04/03

39. Mueller SM, Haeusermann P, Rovo A, Halter JP, Passweg J, Itin P, et al. Genital chronic GVHD in men after hematopoietic stem cell transplantation: a single-center cross-sectional analysis of 155 patients. Biol Blood Marrow Transplant: J Am Soc Blood Marrow Transplant. 2013;19:1574-80. https://doi.org/10.1016/j.bbmt. 2013.07.010. e-pub ahead of print 2013/08/22

40. Williams KM, Cheng GS, Pusic I, Jagasia M, Burns L, Ho VT, et al. Fluticasone, azithromycin, and montelukast treatment for new-onset bronchiolitis obliterans syndrome after hematopoietic cell transplantation. Biol Blood Marrow Transplant: J Am Soc Blood Marrow Transplant. 2016;22:710-6. https://doi.org/10. 1016/j.bbmt.2015.10.009. e-pub ahead of print 2015/10/18

41. Bergeron A, Chevret S, Chagnon K, Godet C, Bergot E, Peffault de Latour R, et al. Budesonide/Formoterol for bronchiolitis obliterans after hematopoietic stem cell transplantation. Am J Respir Crit Care Med. 2015;191:1242-9. https://doi.org/10.1164/ rccm.201410-18180C. e-pub ahead of print 2015/04/04

42. Zecca M, Prete A, Rondelli R, Lanino E, Balduzzi A, Messina C, et al. Chronic graft-versus-host disease in children: incidence, risk factors, and impact on outcome. Blood. 2002;100:1192-200. https://doi.org/10.1182/blood-2001-11-0059. e-pub ahead of print 2002/08/01

43. Dobbelstein C, Ahn KW, Haagenson M, Hale GA, van Rood JJ, Miklos D, et al. Birth order and transplantation outcome in HLAidentical sibling stem cell transplantation: an analysis on behalf of the Center for International Blood and Marrow Transplantation. Biol Blood Marrow Transplant: J Am Soc Blood Marrow Transplant. 2013;19:741-5. https://doi.org/10.1016/j.bbmt.2013. 01.020. e-pub ahead of print 2013/02/06

44. Guardiola P, Socie G, Li X, Ribaud P, Devergie A, Esperou H, et al. Acute graft-versus-host disease in patients with Fanconi anemia or acquired aplastic anemia undergoing bone marrow transplantation from HLA-identical sibling donors: risk factors and influence on outcome. Blood. 2004;103:73-77. https://doi. org/10.1182/blood-2003-06-2146

45. Wiener L, Baird K, Crum C, Powers K, Carpenter P, Baker KS, et al. Child and parent perspectives of the chronic graft-versushost disease (cGVHD) symptom experience: a concept elicitation study. Support Care Cancer: Off J Multinatl Assoc Support Care Cancer. 2014;22:295-305. https://doi.org/10.1007/s00520-0131957-6

46. MacMillan ML, Robin M, Harris AC, DeFor TE, Martin PJ, Alousi A, et al. A refined risk score for acute graft-versus-host disease that predicts response to initial therapy, survival, and transplant-related mortality. Biol Blood Marrow Transplant. 2015;21:761-7. https://doi.org/10.1016/j.bbmt.2015.01.001

47. Flowers ME, Storer B, Carpenter P, Rezvani AR, Vigorito AC, Campregher PV, et al. Treatment change as a predictor of outcome among patients with classic chronic graft-versus-host disease. Biol Blood Marrow Transplant: J Am Soc Blood Marrow Transplant. 2008;14:1380-4. https://doi.org/10.1016/j.bbmt.2008.09.017

48. Sullivan KM, Shulman HM, Storb R, Weiden PL, Witherspoon $\mathrm{RP}, \mathrm{McDonald} \mathrm{GB}$, et al. Chronic graft-versus-host disease in 52 patients: adverse natural course and successful treatment with combination immunosuppression. Blood. 1981;57:267-76. e-pub ahead of print 1981/02/01

49. Sullivan KM, Witherspoon RP, Storb R, Weiden P, Flournoy N, Dahlberg S, et al. Prednisone and azathioprine compared with prednisone and placebo for treatment of chronic graft-v-host disease: prognostic influence of prolonged thrombocytopenia after allogeneic marrow transplantation. Blood. 1988;72:546-54. e-pub ahead of print 1988/08/01

50. Akpek G, Lee SJ, Flowers ME, Pavletic SZ, Arora M, Lee S, et al. Performance of a new clinical grading system for chronic graftversus-host disease: a multicenter study. Blood. 2003;102:802-9. https://doi.org/10.1182/blood-2002-10-3141

51. Arora M, Burns LJ, Davies SM, Macmillan ML, Defor TE, Miller WJ, et al. Chronic graft-versus-host disease: a prospective cohort study. Biol Blood Marrow Transplant: J Am Soc Blood Marrow Transplant. 2003;9:38-45. https://doi.org/10.1053/bbmt.2003. 50003. e-pub ahead of print 2003/01/21

52. Wingard JR, Majhail NS, Brazauskas R, Wang Z, Sobocinski KA, Jacobsohn D, et al. Long-term survival and late deaths after allogeneic hematopoietic cell transplantation. J Clin Oncol: Off J Am Soc Clin Oncol. 2011;29:2230-9. https://doi.org/10.1200/ JCO.2010.33.7212

53. Grube M, Holler E, Weber D, Holler B, Herr W, Wolff D. Risk factors and outcome of chronic graft-versus-host disease after allogeneic stem cell transplantation-results from a single-center observational study. Biol Blood Marrow Transplant: J Am Soc 
Blood Marrow Transplant. 2016;22:1781-91. https://doi.org/10. 1016/j.bbmt.2016.06.020. e-pub ahead of print 2016/06/28

54. Kanda J, Nakasone H, Atsuta Y, Toubai T, Yokoyama H, Fukuda $\mathrm{T}$, et al. Risk factors and organ involvement of chronic GVHD in Japan. Bone Marrow Transplant. 2014;49:228-35. https://doi.org/ 10.1038/bmt.2013.151. e-pub ahead of print 2013/10/01

55. Kuzmina Z, Eder S, Bohm A, Pernicka E, Vormittag L, Kalhs P, et al. Significantly worse survival of patients with NIH-defined chronic graft-versus-host disease and thrombocytopenia or progressive onset type: results of a prospective study. Leukemia. 2012;26:746-56. https://doi.org/10.1038/leu.2011.257. e-pub ahead of print 2011/09/20

56. Pérez-Simón JA, Encinas C, Silva F, Arcos MJ, Díez-Campelo M, Sánchez-Guijo FM, et al. Prognostic factors of chronic graftversus-host disease following allogeneic peripheral blood stem cell transplantation: The National Institutes Health Scale plus the type of onset can predict survival rates and the duration of immunosuppressive therapy. Biol Blood Marrow Transplant. 2008; 14:1163-71. https://doi.org/10.1016/j.bbmt.2008.07. 015

57. Pidala J, Kim J, Anasetti C, Nishihori T, Betts B, Field T, et al. The global severity of chronic graft-versus-host disease, determined by National Institutes of Health consensus criteria, is associated with overall survival and non-relapse mortality. Haematologica. 2011;96:1678-84. https://doi.org/10.3324/haematol. 2011.049841. e-pub ahead of print 2011/07/28

58. Foss FM, DiVenuti GM, Chin K, Sprague K, Grodman H, Klein A, et al. Prospective study of extracorporeal photopheresis in steroid-refractory or steroid-resistant extensive chronic graftversus-host disease: analysis of response and survival incorporating prognostic factors. Bone Marrow Transplant. 2005;35:1187-93.

59. Jones D, Zakaria M, Yang M, Larratt L, Turner R, Brown C, et al. Progressive vs non-progressive onset of chronic GVHD after ATG prophylaxis is highly predictive of outcome. Biol Blood Marrow Transplant. 2013;19:S327 https://doi.org/10.1016/j.bbmt.2012.11.495

60. Stewart BL, Storer B, Storek J, Deeg HJ, Storb R, Hansen JA, et al. Duration of immunosuppressive treatment for chronic graftversus-host disease. Blood. 2004;104:3501-6. https://doi.org/10. 1182/blood-2004-01-0200

61. Hsu B, May R, Carrum G, Krance R, Przepiorka D. Use of antithymocyte globulin for treatment of steroid-refractory acute graft-versus-host disease: an international practice survey. Bone Marrow Transplant. 2001;28:945-50. https://doi.org/10.1038/sj. bmt.1703269. e-pub ahead of print 2001/12/26

62. Khoury H, Kashyap A, Adkins DR, Brown RA, Miller G, Vij R, et al. Treatment of steroid-resistant acute graft-versus-host disease with anti-thymocyte globulin. Bone Marrow Transplant. 2001;27:1059-64. https://doi.org/10.1038/sj.bmt.1703032. e-pub ahead of print 2001/07/05

63. Wolff D, Roessler V, Steiner B, Wilhelm S, Weirich V, Brenmoehl J, et al. Treatment of steroid-resistant acute graft-versushost disease with daclizumab and etanercept. Bone Marrow Transplant. 2005;35:1003-10. https://doi.org/10.1038/sj.bmt. 1704929. e-pub ahead of print 2005/04/05

64. Deeg HJ. How I treat refractory acute GVHD. Blood. 2007;109:4119-26. https://doi.org/10.1182/blood-2006-12-041889

65. Furlong T, Martin P, Flowers ME, Carnevale-Schianca F, Yatscoff R, Chauncey $\mathrm{T}$, et al. Therapy with mycophenolate mofetil for refractory acute and chronic GVHD. Bone Marrow Transplant. 2009;44:739-48. https://doi.org/10.1038/bmt.2009. 76. e-pub ahead of print 2009/04/21

66. Pidala J, Kim J, Roman-Diaz J, Shapiro J, Nishihori T, Bookout $\mathrm{R}$, et al. Pentostatin as rescue therapy for glucocorticoid-refractory acute and chronic graft-versus-host disease. Ann Transplant. 2010;15:21-29. e-pub ahead of print 2010/12/25
67. Hoda D, Pidala J, Salgado-Vila N, Kim J, Perkins J, Bookout R, et al. Sirolimus for treatment of steroid-refractory acute graftversus-host disease. Bone Marrow Transplant. 2010;45:1347-51. https://doi.org/10.1038/bmt.2009.343. e-pub ahead of print 2009/ $12 / 08$

68. Das-Gupta E, Greinix H, Jacobs R, Zhou L, Savani BN, Engelhardt BG, et al. Extracorporeal photopheresis as second-line treatment for acute graft-versus-host disease: impact on six-month freedom from treatment failure. Haematologica. 2014;99:1746-52. https://doi.org/10.3324/haematol.2014.108217

69. Khandelwal P, Teusink-Cross A, Davies SM, Nelson AS, Dandoy $\mathrm{CE}$, El-Bietar J, et al. Ruxolitinib as salvage therapy in steroidrefractory acute graft-versus-host disease in pediatric hematopoietic stem cell transplant patients. Biol Blood Marrow Transplant. 2017;23:1122-7. https://doi.org/10.1016/j.bbmt.2017.03. 029

70. Dotoli GM, De Santis GC, Orellana MD, de Lima Prata K, Caruso SR, Fernandes TR, et al. Mesenchymal stromal cell infusion to treat steroid-refractory acute GvHD III/IV after hematopoietic stem cell transplantation. Bone Marrow Transplant. 2017;52:859-62. https://doi.org/10.1038/bmt.2017.35

71. Socié G, Vigouroux S, Yakoub-Agha I, Bay J-O, Fürst S, Bilger $\mathrm{K}$. et al. A phase 3 randomized trial comparing inolimomab vs usual care in steroid-resistant acute GVHD. Blood. 2017;129:643-9. https://doi.org/10.1182/blood-2016-09-738625.

72. MacMillan ML, Weisdorf DJ, Davies SM, DeFor TE, Burns LJ, Ramsay NKC, et al. Early antithymocyte globulin therapy improves survival in patients with steroid-resistant acute graft-versus-host disease. Biol Blood Marrow Transplant. 2002;8:40-46. https://doi. org/10.1053/bbmt.2002.v8.pm11858189

73. Bolanos-Meade J, Jacobsohn DA, Margolis J, Ogden A, Wientjes MG, Byrd JC, et al. Pentostatin in steroid-refractory acute graftversus-host disease. J Clin Oncol: Off J Am Soc Clin Oncol. 2005;23:2661-8. https://doi.org/10.1200/jco.2005.06.130. e-pub ahead of print 2005/04/20

74. Shapira MY, Resnick IB, Bitan M, Ackerstein A, Tsirigotis P, Gesundheit B, et al. Rapid response to alefacept given to patients with steroid resistant or steroid dependent acute graft-versus-host disease: a preliminary report. Bone Marrow Transplant. 2005;36:1097-101.

75. Jackson K, Curley C, Leach J, McLean A, Nakagaki M, Durrant $\mathrm{S}$, et al. Alemtuzumab as salvage therapy for steroid and ATG/ etanercept-refractory acute GVHD. Bone Marrow Transplant. 2011;46:1579-80. https://doi.org/10.1038/bmt.2010.341. e-pub ahead of print 2011/01/25

76. Strong Rodrigues K, Oliveira-Ribeiro C, de Abreu Fiuza Gomes $\mathrm{S}$, Knobler R. Cutaneous graft-versus-host disease: diagnosis and treatment. Am J Clin Dermatol. 2017. https://doi.org/10.1007/ s40257-017-0306-9

77. Bay JO, Dhedin N, Goerner M, Vannier JP, Marie-Cardine A, Stamatoullas A, et al. Inolimomab in steroid-refractory acute graft-versus-host disease following allogeneic hematopoietic stem cell transplantation: retrospective analysis and comparison with other interleukin-2 receptor antibodies. Transplantation. 2005;80:782-8. e-pub ahead of print 2005/10/08

78. Martinez C, Solano C, Ferra C, Sampol A, Valcarcel D, PerezSimon JA. Alemtuzumab as treatment of steroid-refractory acute graft-versus-host disease: results of a phase II study. Biol Blood Marrow Transplant: J Am Soc Blood Marrow Transplant. 2009;15:639-42. https://doi.org/10.1016/j.bbmt.2009.01.014. epub ahead of print 2009/04/14

79. Shapira MY, Klimov A, Vipul S, Grisariu S, Avni BR, Or R, et al. Regional intra-arterial steroid treatment in 120 patients with steroid-resistant or -dependent GvHD. Bone Marrow Transplant. 2017. e-pub ahead of print 2017/06/27; https://doi.org/10.1038/ bmt.2017.120 
80. Greinix HT, Volc-Platzer B, Kalhs P, Fischer G, Rosenmayr A, Keil F, et al. Extracorporeal photochemotherapy in the treatment of severe steroid-refractory acute graft-versus-host disease: a pilot study. Blood. 2000;96:2426-31.

81. Greinix H, Knobler R, Worel N, Schneider B, Schneeberger A, Hoecker P, et al. The effect of intensified extracorporeal photochemotherapy on long-term survival in patients with severe acute graft-versus-host disease. Haematologica. 2006;91:405-8.

82. Van Lint MT, Milone G, Leotta S, Uderzo C, Scimè R, Dallorso $\mathrm{S}$, et al. Treatment of acute graft-versus-host disease with prednisolone: significant survival advantage for day +5 responders and no advantage for nonresponders receiving anti-thymocyte globulin. Blood. 2006;107:4177-81. https://doi.org/10.1182/ blood-2005-12-4851

83. Perfetti P, Carlier P, Strada P, Gualandi F, Occhini D, Van Lint MT, et al. Extracorporeal photopheresis for the treatment of steroid refractory acute GVHD. Bone Marrow Transplant. 2008;42:609-17. https://doi.org/10.1038/bmt.2008.221. e-pub ahead of print 2008/07/29

84. Dignan FL, Clark A, Amrolia P, Cornish J, Jackson G, Mahendra $\mathrm{P}$, et al. Diagnosis and management of acute graft-versus-host disease. Br J Haematol. 2012;158:30-45. https://doi.org/10.1111/ j.1365-2141.2012.09129.x. e-pub ahead of print 2012/04/27

85. Ruutu T, Gratwohl A, de Witte T, Afanasyev B, Apperley J, Bacigalupo A, et al. Prophylaxis and treatment of GVHD: EBMTELN working group recommendations for a standardized practice. Bone Marrow Transplant. 2014;49:168-73. https://doi.org/10. 1038/bmt.2013.107. e-pub ahead of print 2013/07/31

86. Furlong T, Leisenring W, Storb R, Anasetti C, Appelbaum FR, Carpenter PA, et al. Psoralen and ultraviolet A irradiation (PUVA) as therapy for steroid-resistant cutaneous acute graftversus-host disease. Biol Blood Marrow Transplant: J Am Soc Blood Marrow Transplant. 2002;8:206-12. e-pub ahead of print 2002/05/17

87. Martin PJ, Lee SJ, Przepiorka D, Horowitz MM, Koreth J, Vogelsang GB, et al. National Institutes of Health Consensus
Development Project on Criteria for Clinical Trials in Chronic Graft-versus-Host Disease: VI. The 2014 Clinical Trial Design Working Group Report. Biol Blood Marrow Transplant: J Am Soc Blood Marrow Transplant. 2015;21:1343-59. https:// doi.org/10.1016/j.bbmt.2015.05.004. e-pub ahead of print 2015/ $05 / 20$

88. Wolff D, Gerbitz A, Ayuk F, Kiani A, Hildebrandt GC, Vogelsang GB, et al. Consensus conference on clinical practice in chronic graft-versus-host disease (GVHD): first-line and topical treatment of chronic GVHD. Biol Blood Marrow Transplant: J Am Soc Blood Marrow Transplant. 2010;16:1611-28. https://doi. org/10.1016/j.bbmt.2010.06.015. e-pub ahead of print 2010/07/06

89. Cutler C, Miklos D, Kim HT, Treister N, Woo S-B, Bienfang D, et al. Rituximab for steroid-refractory chronic graft-versus-host disease. Blood. 2006;108:756-62. https://doi.org/10.1182/blood2006-01-0233

90. Martin PJ, Schoch G, Fisher L, Byers V, Appelbaum FR, McDonald GB, et al. A retrospective analysis of therapy for acute graft-versus-host disease: secondary treatment. Blood. 1991;77:1821-8. e-pub ahead of print 1991/04/15

91. Wolff D, Schleuning M, von Harsdorf S, Bacher U, Gerbitz A, Stadler M, et al. Consensus conference on clinical practice in chronic GVHD: second-line treatment of chronic graft-versus-host disease. Biol Blood Marrow Transplant: J Am Soc Blood Marrow Transplant. 2011;17:1-17. https://doi.org/10.1016/j.bbmt.2010. 05.011. e-pub ahead of print 2010/08/06

92. Flowers ME, Apperley JF, van Besien K, Elmaagacli A, Grigg A, Reddy V, et al. A multicenter prospective phase 2 randomized study of extracorporeal photopheresis for treatment of chronic graft-versus-host disease. Blood. 2008;112:2667-74. https://doi. org/10.1182/blood-2008-03-141481

93. Ruutu T, Gratwohl A, Niederwieser D, de Witte T, van der Werf $\mathrm{S}$, van Biezen A, et al. The EBMT-ELN working group recommendations on the prophylaxis and treatment of GvHD: a changecontrol analysis. Bone Marrow Transplant. 2017;52:357-62. https://doi.org/10.1038/bmt.2016.298 